\title{
Ecology of European Brown Hare and Distribution of Natural Foci of Tularaemia in the Czech Republic
}

\author{
J. PIKULA ${ }^{1}$, M. BEKLOVÁ ${ }^{1}$, Z. HOLEŠOVSKÁ ${ }^{1}$, F. TREML ${ }^{2}$ \\ ${ }^{1}$ Department of Veterinary Ecology and Environmental Protection \\ ${ }^{2}$ Department of Infectious Diseases and Epizootiology \\ University of Veterinary and Pharmaceutical Sciences, Brno, Czech Republic
}

Received June 16, 2003

Accepted June 17, 2004

\begin{abstract}
Pikula J., M. Beklová, Z. Holešovská, F. Treml: Ecology of European Brown Hare and Distribution of Natural Foci of Tularaemia in the Czech Republic. Acta Vet. Brno 2004, 73: 267-273.

Quantitative data on the geographic distribution of the European brown hare in the Czech Republic were analysed using a geographic information system with respect to selected environmental factors and natural foci of tularaemia. The highest population densities of the European brown hare were found in geographic areas of up to $200 \mathrm{~m}$ of elevation above sea (231.47 individuals $/ 10 \mathrm{~km}^{2}$ ), climatic district No. 1 (227.91 individuals/10 $\mathrm{km}^{2}$ ), annual snow cover duration of 40-60 days (183.95 individuals $/ 10 \mathrm{~km}^{2}$ ), mean annual precipitation of 450-700 $\mathrm{mm}$ (174.71 individuals/10 $\mathrm{km}^{2}$ ), annual sunshine duration of 1801-2000 hour (169.72 individuals $/ 10 \mathrm{~km}^{2}$ ) and mean annual air temperature of over $10.0{ }^{\circ} \mathrm{C}$ (245.00 individuals / $\left./ 10 \mathrm{~km}^{2}\right)$. A correlation $(\mathrm{r}=0.443, \mathrm{n}=395, \mathrm{t}=9.797, p=0.01)$ between the population density of the European brown hare and numbers of natural foci of tularaemia in the Czech Republic was found. In other words, tularaemia seems to be dependent on the population density of the European brown hare.
\end{abstract}

Lepus europaeus, habitats, population density, environmental factors, Francisella tularensis

The European brown hare (Lepus europaeus) is one of the most important game species, the ecological conditions of distribution as well as population density of which are studied with respect to hunting economics and quota (Klansek et al. 1998; Strauss and Pohlmeyer 2001). It is, however, also a reservoir host of a zoonotic disease - tularaemia, the ecology of which may be a part of epizootiological and epidemiological studies (Pikula 1996). As a part of such studies it is possible to examine the geographic distribution of the host defining the maximum range the disease can occur, range of the pathogen distribution within the range of the host, associations between the geographic distribution of the host and pathogen within specific habitats, population density and ecological requirements of the host (Pikula et al. 2002). Natural foci of tularaemia are common in the Czech Republic and in this respect it seems to be a re-emerging disease both due to its incidence and prevalence in wild animals and humans during the last decade (Guryčová 2001). Though several mammals play a role as reservoir hosts in natural foci of tularaemia, the European brown hare seems to be the most important one in terms of public health concern.

The aim of the paper, therefore, is to evaluate some aspects of ecological distribution of the European brown hare - one of the main reservoir hosts of tularaemia (Hubálek et al. 1993; Hoflechner-Poltl et al. 2000) in relation to the distribution of tularaemia in the Czech Republic.

\footnotetext{
Address for correspondence:

MVDr. Jiří Pikula, Ph.D.

Department of Veterinary Ecology and Environmental Protection

University of Veterinary and Pharmaceutical Sciences

Palackého 1-3, 61242 Brno

Czech Republic
}

Phone: + 420541562655

E-mail: pikulaj@vfu.cz

http://www.vfu.cz/acta-vet/actavet.htm 


\section{Materials and Methods}

For purposes of evaluating the ecology of distribution of the European brown hare in relation to the distribution of natural foci of tularaemia we used geographic computer databases on spatial distribution of environmental factors including the following maps:

1. Hypsometric geographic map of the Czech Republic divided into areas characterised by the elevation above sea of up to 200, 201-400, 401-600, 601-800, 801-1000 and over $1000 \mathrm{~m}$.

2. Climatic map of the Czech Republic encompassing such climatic areas as: $1=$ a warm and dry district with mild winter and longer duration of sunshine; a warm and dry district with mild winter and shorter duration of sunshine; a warm and moderately dry district with mild winter; 2 = a warm and moderately dry district with cold winter; 3 = a warm and moderately humid district with mild winter; a warm and moderately humid district with cold winter; 4 = a moderately humid and dry district with mild winter; a moderately warm and dry district, mostly with mild winter; $5=$ a moderately warm and moderately humid district with mild winter of the hilly country; a moderately warm and moderately humid district with cold winter of valleys; a moderately warm and moderately humid district of highlands; $6=$ a warm and moderately humid district with mild winter in hilly country and on plains; a moderately warm and humid district with cold or cool winter in valleys; a moderately warm and humid district in highlands; $7=$ a moderately warm and very humid district in hilly country; $8=$ a moderately cold district; $9=$ a cold district of mountains; a chilly district of mountains. Larger climatic units in the Czech Republic, i.e., warm climatic regions, moderately warm climatic regions and cold regions include the above districts 1 to 3,4 to 8 and 9, respectively.

3. Map of the Czech Republic showing snow cover in different areas lasting 40-60, 61-120, 121-180, 181-200 days in a year.

4. Mean annual precipitation map of the Czech Republic divided into areas characterised by precipitation levels of 450-700, 701-1000, 1001-1400 and 1401-1800 mm.

5. Sunshine duration map of the Czech Republic divided into areas characterised by the mean annual sunshine lasting up to 1600, 1601-1800, 1801-2000 and 2001-2200 hour.

6. Mean annual air temperature map of the Czech Republic divided into categories of over 10.0, 8.1-10.0, 6.1-8.0, 4.1-6.0, 2.1-4.0 and $0.0-2.0^{\circ} \mathrm{C}$.

The above-mentioned databases representing 50-year mean values of the above-listed environmental factors have already been described (Pikula and Beklová 1987).

7. Database containing the mean spatial distribution of natural foci of tularaemia during years of 1971 to 2000 in the Czech Republic. Source data were obtained from the Monthly reports on infectious diseases in animals by the State Veterinary Administration of the Czech Republic and saved as a map of mean numbers of natural foci of tularaemia in unit areas of the database during the 30-year study period. For a description of this database cf. Pikula et al. (2002).

8. Database containing the mean spatial distribution of the European brown hare population throughout the Czech Republic. This geographic database was divided into areas where the European hare population amounted to the density of 1-50, 51-100, 101-150, 151-200, 201-250 and over 250 individuals $/ 10 \mathrm{~km}^{2}$, on average, in the longterm perspective of 30 years. Source data were obtained from bag records published from statistical data of the Ministry of Agriculture of the Czech Republic. For a description of this database cf. Pikula (1996).

Analytical tools of the KORMAP GIS program were employed to evaluate statistically the environmental conditions of distribution of European brown hare and its relation to the distribution of natural foci of tularaemia in the Czech Republic. The whole territory of the Czech Republic was divided into 1814 unit areas characterised by specific conditions. The distribution and numbers of the European brown hare in unit areas of $5.1 \times 8.5 \mathrm{~km}$ were checked against databases of the above-mentioned environmental factors to obtain frequency tables, from which we computed the mean number of the European brown hare in a specific area. The frequency table was then further used to compute the coefficient of correlation between the two variables related, i.e., numbers of European brown hare and numbers of natural foci of tularaemia. Differences in the variance of samples of numbers of the European brown hare in specific areas of environmental factors were tested by F-test. Statistical significance of at least $p=0.05$ was acceptable in testing the differences and correlation. For more details of the methods and material see Pikula and Beklová (1987) and Pikula et al. (2002, 2003).

\section{Results}

Distribution of the European brown hare in relation to various factors of the environment in the Czech Republic

Results on the mean numbers of the European brown hare (population density) in relation to elevation above sea, climatic areas, snow cover duration, mean annual precipitation, mean annual sunshine duration and mean annual air temperature are summarised in Tables 1-6, respectively. 
Testing the variance of mean numbers of the European brown hare (population density) in specific areas characterised by individual environmental factors (i.e., within Tables 1-6) resulted in finding statistically significant differences ( $p=0.05$ and 0.01 , respectively). In the Czech Republic the European brown hare population reaches maximum levels of its density in areas characterised by following conditions: elevation above sea of up to $200 \mathrm{~m}$, climatic district No 1, 40-60 d of snow cover duration a year, 450-700 mm of mean annual precipitation, $1801-2000 \mathrm{~h}$ of sunshine duration a year and over $10.0^{\circ} \mathrm{C}$ of mean annual air temperature.

Table 1

Mean population densities of European brown hare in areas of different elevation above sea in the Czech Republic

\begin{tabular}{|l|c|c|c|}
\hline & \multicolumn{3}{|c|}{$\begin{array}{c}\text { Population density of } \\
\text { European brown hare (individuals/10 } \mathrm{km}^{2} \text { ) }\end{array}$} \\
\hline $\begin{array}{l}\text { Areas characterised by the } \\
\text { elevation above sea }\end{array}$ & Mean & $\begin{array}{c}\text { Number } \\
\text { of unit areas }\end{array}$ & $\begin{array}{c}\text { Standard } \\
\text { deviation }\end{array}$ \\
\hline Up to 200 & 231.47 & 116 & 55.91 \\
\hline $201-400$ & 183.18 & 556 & 70.14 \\
\hline $401-600$ & 140.13 & 694 & 59.67 \\
\hline $601-800$ & 110.09 & 342 & 53.64 \\
\hline $801-1000$ & 58.97 & 78 & 39.62 \\
\hline Over $1000 \mathrm{~m}$ & 44.64 & 28 & 33.65 \\
\hline
\end{tabular}

Table 2

Mean population densities of European brown hare in individual climatic areas in the Czech Republic

\begin{tabular}{|l|c|c|c|}
\hline & \multicolumn{3}{|c|}{$\begin{array}{c}\text { Population density of } \\
\text { burown hare (individuals } / 10 \mathrm{~km}^{2} \text { ) }\end{array}$} \\
\hline Climatic districts & Mean & $\begin{array}{c}\text { Number } \\
\text { of unit areas }\end{array}$ & $\begin{array}{c}\text { Standard } \\
\text { deviation }\end{array}$ \\
\hline 1 & 227.91 & 189 & 55.20 \\
\hline 2 & - & - & - \\
\hline 3 & 170.31 & 32 & 62.95 \\
\hline 4 & 197.82 & 287 & 67.64 \\
\hline 5 & 152.59 & 725 & 56.24 \\
\hline 6 & 121.38 & 235 & 51.96 \\
\hline 7 & 84.18 & 147 & 38.25 \\
\hline 8 & 64.25 & 186 & 42.34 \\
\hline 9 & 50.00 & 12 & 43.30 \\
\hline
\end{tabular}

Table 3

Mean population densities of European brown hare in individual areas characterised by snow cover duration in a year in the Czech Republic

\begin{tabular}{|l|c|c|c|}
\hline & \multicolumn{3}{|c|}{ Population density of } \\
& European brown hare (individuals $/ 10 \mathrm{~km}^{2}$ ) \\
\hline Snow cover duration in a year & Mean & $\begin{array}{c}\text { Number } \\
\text { of unit areas }\end{array}$ & $\begin{array}{c}\text { Standard } \\
\text { deviation }\end{array}$ \\
\hline 40- 60 days & 183.95 & 905 & 67.16 \\
\hline 61-120 days & 119.47 & 823 & 58.82 \\
\hline 121-180 days & 53.29 & 76 & 34.73 \\
\hline 181-200 days & 50.00 & 10 & 46.10 \\
\hline
\end{tabular}


Table 4

Mean population densities of European brown hare in individual areas characterised by mean annual precipitation in the Czech Republic

\begin{tabular}{|l|c|c|c|}
\hline & \multicolumn{3}{|c|}{ Population density of } \\
& European brown hare (individuals $/ 10 \mathrm{~km}^{2}$ ) \\
\hline Mean annual precipitation in $\mathrm{mm}$ & Mean & $\begin{array}{c}\text { Number } \\
\text { of unit areas }\end{array}$ & $\begin{array}{c}\text { Standard } \\
\text { deviation }\end{array}$ \\
\hline $450-700$ & 174.71 & 1217 & 65.73 \\
\hline $701-1000$ & 102.14 & 490 & 56.32 \\
\hline $1001-1400$ & 66.18 & 85 & 41.43 \\
\hline $1401-1800$ & 47.73 & 22 & 24.90 \\
\hline
\end{tabular}

Table 5

Mean population densities of European brown hare in areas characterised by different sunshine duration in a year in the Czech Republic

\begin{tabular}{|l|c|c|c|}
\hline & \multicolumn{3}{|c|}{ Population density of } \\
& European brown hare (individuals $/ 10 \mathrm{~km}^{2}$ ) \\
\hline Sunshine duration in hours & Mean & $\begin{array}{c}\text { Number } \\
\text { of unit areas }\end{array}$ & $\begin{array}{c}\text { Standard } \\
\text { deviation }\end{array}$ \\
\hline up to 1600 & 70.62 & 160 & 50.74 \\
\hline $1601-1800$ & 144.83 & 905 & 66.16 \\
\hline $1801-2000$ & 169.72 & 738 & 73.06 \\
\hline $2001-2200$ & 156.82 & 11 & 53.40 \\
\hline
\end{tabular}

Table 6

Mean population densities of European brown hare in areas characterised by mean annual air temperature in the Czech Republic

\begin{tabular}{|l|c|c|c|}
\hline & \multicolumn{3}{|c|}{ Population density of } \\
\hline Mean annual air temperature & Mean & $\begin{array}{c}\text { Number } \\
\text { of unit areas }\end{array}$ & $\begin{array}{c}\text { Standard } \\
\text { deviation }\end{array}$ \\
\hline over $10.0^{\circ} \mathrm{C}$ & 245.00 & 5 & 60.00 \\
\hline $8.1-10.0^{\circ} \mathrm{C}$ & 208.13 & 403 & 68.49 \\
\hline $6.1-8.0^{\circ} \mathrm{C}$ & 144.69 & 1115 & 60.46 \\
\hline $4.1-6.0^{\circ} \mathrm{C}$ & 82.59 & 257 & 52.48 \\
\hline $2.1-4.0^{\circ} \mathrm{C}$ & 50.86 & 29 & 36.25 \\
\hline $0.0-2.0^{\circ} \mathrm{C}$ & 62.50 & 4 & 21.65 \\
\hline
\end{tabular}

Relation between population levels of the European brown hare and numbers of natural foci of tularaemia in the Czech Republic

Correlation analysis was used to test the relation between the population density and geographic distribution of the European brown hare in relation to natural foci of tularaemia in the Czech Republic. For this purpose we used the database on long-term quantitative geographic distribution of the European brown hare in the Czech Republic and the database including the mean spatial distribution of natural foci of tularaemia in the European brown hare during years of 1971 to 2000. A correlation between the European brown hare population density and numbers of natural foci of tularaemia $(r=0.443, n=395, t=9.797$, $p=0.01$ ) was found. In other words, tularaemia seems to be the European brown hare population density dependent. The higher the population density of the European brown hare, the higher the number of natural foci of tularaemia in a given area. 


\section{Discussion}

Descriptions of habitats inhabited by the European brown hare (Lepus europaeus) are found in most textbooks on mammals (cf., e.g., Niethammer and Krapp 2003). According to Nowak and Paradiso (1983), this species may occupy either open country (often cultivated land) or forest. Gaffrey (1961) provides somewhat more precise description listing such habitats as open land, fields, meadows, forests and forest clearings, shrubs and trees within fields, and field edges. Pelikán et al. (1979) mentions the European brown hare inhabiting the whole territory of Czechoslovakia, especially lowlands, and, on occasion, areas above the tree-line in mountains, i.e., in areas of about 1500 metres above sea level. It is mostly found in cultivated land of lowland steppes, warm hilly country, sometimes deep in the forest and city outskirts. The above descriptions, however, are only verbal and lack any characteristics of quantitative data on the geographic distribution and population density of the European brown hare for a comparison with our results to be made. To our knowledge, no one has ever used a geographic information system to correlate population densities of the European brown hare and habitats of its distribution including environmental factors on a large scale basis. There are, nevertheless, some papers evaluating these aspects in a smaller geographic area. For example, in 1987-1990 Le w and ow ski and Now akow ski (1993) made an investigation on the spatial structure of the European brown hare populations using the transect routes method in two different parts of Poland that differed in the character of agriculture. Their results indicate that independently of the agrarian structure, the distribution of hares in crops corresponds to their percentage share in the region, with exception of rape fields, which show a tendency to be avoided. There was also a significant relationship between the spatial distribution of the hare and the habitat diversity - highly variegated fields were more consistently inhabited by hares. Besides, hares show a distinct tendency to prefer areas close to the field margins. According to V a u ghan et al. (2003), hares were relatively common on arable farms, especially on those with wheat (Triticum aestivum), beet (Beta vulgaris) or fallow land. They were less common on pastural farms. Panek and Kamieniarz (1999) found the density of the European brown hare in different landscape areas of Poland between 1981-1995 to be ranging from 0.07 to $5.18 \mathrm{ind} / \mathrm{km}^{2}$ (hunting bag). Strauss and Pohlmeyer (2001) recorded the greatest abundancies with 24.8-27.6 hares $/ \mathrm{km}^{2}$ during years 1995-1999 in the county of Wesermarsch (Lower Saxony, Germany) which is quite comparable to our study.

Considering the relation between the European brown hare population density and numbers of natural foci of tularaemia in the Czech Republic, a correlation $(r=0.443, n=$ $395, \mathrm{t}=9.797, p=0.01$ ) was found. In other words, tularaemia seems to be the European brown hare population density dependent. The highest population densities of the European brown hare were found in geographic areas of up to $200 \mathrm{~m}$ of elevation above sea (231.47 individuals $/ 10 \mathrm{~km}^{2}$ ), climatic district No. 1 (227.91 individuals $/ 10 \mathrm{~km}^{2}$ ), snow cover duration of 40-60 days in a year (183.95 individuals/10 $\left.\mathrm{km}^{2}\right)$, mean annual precipitation of $450-700 \mathrm{~mm}$ (174.71 individuals $\left./ 10 \mathrm{~km}^{2}\right)$, sunshine duration in a year of 1801-2000 hour (169.72 individuals $\left./ 10 \mathrm{~km}^{2}\right)$ and mean annual air temperature of over $10.0{ }^{\circ} \mathrm{C}(245.00$ individuals $/ 10 \mathrm{~km}^{2}$ ). Pikula et al. (2003) found tularaemia to be most prevalent in habitats of alluvial forests $\left(x_{t}=7.20\right)$, geographic areas of up to $200 \mathrm{~m}$ of elevation above sea $\left(x_{t}=\right.$ 9.18), 8.1-10.0 ${ }^{\circ} \mathrm{C}$ of mean annual air temperature $\left(\mathrm{x}_{\mathrm{t}}=6.24\right), 450-700 \mathrm{~mm}$ of mean annual precipitation $\left(\mathrm{x}_{\mathrm{t}}=2.84\right)$, and 2001-2200 h of mean annual sunshine duration $\left(\mathrm{x}_{\mathrm{t}}=8.77\right)$. It can, therefore, be stated that tularaemia is most prevalent in habitats of the highest population density of the European brown hare. This result supports the correlation of the two phenomena evaluated within this study.

There are certainly other factors that play a role in the persistence of tularaemia. Pikula et al. (2002), for example, evaluated the relation between the distribution of natural foci of 
tularaemia and the common vole. Hubálek et al. (1998) examined Dermacentor reticulatus ticks for Francisella tularensis. Guryčová et al. (1995) studied the prevalence of ticks infected with Francisella tularensis in natural foci of tularemia in western Slovakia. Data on the quantitative geographic distribution of ticks and other small rodents participating in the circulation of Francisella tularensis in the Czech Republic, however, are lacking to be included in a study like this.

There are only a few studies evaluating the interaction between the size of a population of some wild animal species and infectious diseases. Dobs on and Meagher (1996) made such an evaluation regarding brucellosis and bison in Yellowstone National Park. It was found that brucellosis has a sharply defined critical threshold for establishment and maintenance within the population. Brucellosis will persist in bison populations of 200 individuals or larger.

No such a critical threshold has yet been determined for tularaemia and the European brown hare. We can, however, speculate that the same principle takes part in the persistence of tularaemia in natural foci in the Czech Republic and that other reservoir animals - rodents enable lower population levels to suffice for the critical threshold. These are, however, theoretical hypotheses requiring further studies to be confirmed.

\section{Ekologie zajíce polního a rozšíření přírodních ohnisek tularémie v České republice}

S využitím geografického informačního systému byla analyzována kvantitativní data o geografickém rozšíření zajíce polního v České republice s ohledem na vybrané faktory prostředí a výskyt přírodních ohnisek tularémie. Nejvyšší hustota populace zajíce polního byla zjištěna v geografických oblastech o nadmořské výšce do 200 metrů $(231,47$ jedinců/10 km²), v klimatickém okrsku č. 1 (227,91 jedinců/10 km²), v oblastech se sněhovou pokrývkou ležící 40-60 dní v roce $(183,95$ jedinců/10 km²), v oblastech s průměrnými ročními srážkami 450 až $700 \mathrm{~mm}\left(174,71\right.$ jedinců/ $\left.10 \mathrm{~km}^{2}\right)$, v oblastech s roční délkou slunečního svitu 1 $801-2000$ hodin $(169,72$ jedinců/10 km²) a v oblastech s průměrnou roční teplotou vzduchu $10,0{ }^{\circ} \mathrm{C}$ a více $\left(245,00\right.$ jedinců $\left./ 10 \mathrm{~km}^{2}\right)$. Dále byla zjištěna korelace $(\mathrm{r}=0,443 ; \mathrm{n}=395$; $\mathrm{t}=9,797 ; p=0,01)$ mezi populační hustotou zajíce polního a početností přírodních ohnisek tularémie v České republice. Jinými slovy, tularémie je závislá na populační hustotě zajíce polního.

\section{Acknowledgements}

This study was supported by the Research Project of the Ministry of Education, Youth and Sports of the Czech Republic J16/98:162700004.

\section{References}

DOBSON, A, MEAGHER, M 1996: The population dynamics of brucellosis in Yellowstone National Park. Ecology 77: 1026-1036

GAFFREY, G 1961: Merkmale der wildlebenden Säugetiere Mitteleuropas. Leipzig. 215 p.

GURYČOVÁ, D, KOCIÁNOVÁ, E, VÝROSTEKOVÁ, V, ŘEHÁČEK, J 1995: Prevalence of ticks infected with Francisella tularensis in natural foci of tularemia in western Slovakia. Eur J Epidem 11: 469-474

GURYČOVÁ, D, VYROSTEKOVÁ, V, KHANAKAH, G, KOCIÁNOVÁ, E, STANĚK, G 2001: Importance of surveillance of tularemia natural foci in the known endemic area of Central Europe, 1991-1997. Wiener Klin Wochenschrift 113: 433-438

HOFLECHNER-POLTL, A, HOFER, E, AWAD-MASALMEH, M, MULLER, M, STEINECK, T 2000: Prevalence of tularaemia and brucellosis in European brown hares (Lepus europaeus) and red foxes (Vulpes vulpes) in Austria. Tierärzt Umschau 55: 264-268

HUBÁLEK, Z, JUŘICOVÁ, Z, SVOBODOVÁ, S, HALOUZKA, J 1993: A serologic survey for some bacterial and viral zoonoses in game animals in the Czech Republic. J Wildlife Dis 29: 604-607

HUBÁLEK, Z, SIXL, W, HALOUZKA, J 1998: Francisella tularensis in Dermacentor reticulatus ticks from the Czech Republic and Austria. Wien Klin Wochenschr 110: 909-910 
KLANSEK, E, KALIVODOVÁ, E, SIMONOVIC, V, KURTHY, A 1998: Landscape-ecological evaluation of the flood plain of the river March (Morava) with regard to hare (Lepus europaeus Pallas) and roe deer (Capreolus capreolus L.). Ekológia-Bratislava 17: 201-207

LEWANDOWSKI, K, NOWAKOWSKI, JJ 1993: Spatial distribution of brown hare Lepus europaeus populations in habitats of various types of agriculture. Acta Theriol 38: 435-442

NIETHAMMER, J, KRAPP, F (Eds.) 2003: Handbuch der Säugetiere Europas, Band 3/II: Hasenartige Leporidae. AULA - Verlag Wiesbaden, pp. 303

NOWAK, RM, PARADISO, JL 1983: Walker's Mammals of the World. The Johns Hopkins University Press. Baltimore, London. $4^{\text {th }}$ edition. pp. 488-492

PANEK, P, KAMIENIARZ, R 1999: Relationships between density of brown hare Lepus europaeus and landscape structure in Poland in the years 1981-1995. Acta Theriol 44: 67-75

PELIKÁN, J, GAISLER, J, RÖDL, P 1979: Our mammals. Academia. Praha, 164 p.

PIKULA, J, BEKLOVÁ, M 1987: Ecological distribution of Phasianus colchicus in Czechoslovakia. Acta Sc Nat Brno 21: 1-47

PIKULA, J 1996: Ecological - epizootiological studies into the tularaemia of the European Hare Lepus europaeus Pallas, 1778. Dissertation. VFU Brno, 89 p.

PIKULA, J, TREML, F, BEKLOVÁ, M, HOLEŠOVSKÁ, Z, PIKULOVÁ, J 2002: Geographic information systems in epidemiology - ecology of common vole and distribution of natural foci of tularaemia. Acta Vet Brno 71: $379-387$

PIKULA, J, TREML, F, BEKLOVÁ, M, HOLEŠOVSKÁ, Z, PIKULOVÁ, J 2003: Ecological conditions of natural foci of tularaemia in the Czech Republic. Eur J Epidemiol 18: 1091-1095

STRAUSS, E, POHLMEYER, K 2001: Population density of European hares (Lepus europaeus Pallas, 1778) and hunting activity in Lower Saxony. Z Jagdwiss 47: 43-62

VAUGHAN, N, LUCAS, EA, HARRIS, S, WHITE, PCL 2003: Habitat associations of European hares Lepus europaeus in England and Wales: implications for farmland management. J Appl Ecol 40: 163-175 